\title{
KAMPUNG JAMUR SEBAGAI BENTUK PEMBERDAYAAN MASYARAKAT DI CIKARAU KELURAHAN DADOK TUNGGUL HITAM KECAMATAN KOTO TANGAH KOTA PADANG
}

\author{
Lili Dasa Putri \\ Departemen Pendidikan Luar Sekolah, Universitas Negeri Padang - Indonesia \\ lilidasaputri@fip.unp.ac.id
}

Received: April, 2020; Accepted: Mei, 2020

\begin{abstract}
The mushrooming of oyster mushroom cultivators is caused by the large number of enthusiasts and requests from the community. Mushrooms have many benefits in fulfilling nutrition, in addition to the good taste and cheap to obtain. This was used as an opportunity by the Cikarau community of Dadok Tunggul Hitam Subdistrict, Koto Tangah Subdistrict, Padang City because the land was for business and in order to develop and empower the community. Community empowerment through this mushroom village made many new mushroom cultivators in this area and became a mushroom center. The Cikarau community, besides selling raw mushroom harvests, also empowered them by processing mushrooms into various foods and snacks. With high effort and desire to change destiny through mushroom cultivation, it brings good results and makes people financially and socially empowered. With the results achieved by the community of this mushroom village also brought partners who want to work with the community, especially those who cultivate oyster mushrooms.
\end{abstract}

Keywords: empowerment, mushroom village, oyster mushroom cultivation

\begin{abstract}
Abstrak
Menjamurnya pembudidaya jamur tiram disebabkan oleh banyaknya peminat dan permintaan dari masyarakat. Jamur memiliki banyak manfaat dalam pemenuhan gizi, disamping rasanya yang enak dan murah didapat. Hal ini dijadikan peluang oleh masyarakat Cikarau Kelurahan Dadok Tunggul Hitam Kecamatan Koto Tangah kota Padang sebabagi lahan untuk usaha dan dalam rangka mengembangkan dan memberdayakan masyarakat. Pemberdayaan masyarakat melalui kampung jamur ini membuat banyak lahirnya pembudidaya jamur yang baru didaerah ini dan menjadi sentra jamur. Masyarakat Cikarau selain menjual hasil panen jamur mentah juga memberdayakan dirinya dengan mengolahan jamur menjadi berbagai makanan dan cemilan. Dengan usaha dan keinginan yang tinggi untuk merubah nasib melalui budidaya jamur mendatangkan hasil baik dan membuat masyarakat menjadi berdaya dari segi finansial dan sosial. Dengan hasil yang dicapai oleh masyarakat kampung jamur ini juga mendatangkan mitra yang mau bekerjasama dengan masyarakat khususnya yang membudidayakan jamur tiram ini..
\end{abstract}

Kata Kunci: pemberdayaan, kampung jamur, budidaya jamur tiram

How to Cite: Putri, L.D. (2020). Kampung Jamur Sebagai Bentuk Pemberdayaan Masyarakat Di Cikarau Kelurahan Dadok Tunggul Hitam Kecamatan Koto Tangah Kota Padang. CommEdu (Community Education Journal) 3 (2), 138-143.

\section{PENDAHULUAN}

Budidaya jamur tiram memiliki peluang besar sebagai usaha yang dapat digeluti oleh masyarakat. Saat ini budidaya jamur juga belum banyak dilakukan dan dikembangkan di Indonesia. Jamur tiram ini memiliki peluang sebagai usaha yang dapat digeluti oleh masyarakat 
sebagai pemenuhan kebutuhan sayur-sayuran serta bahan makanan tambahan. Jamur yang sangat diminati oleh masyarakat ini mengandung gizi yang tinggi dan kahasiat yang banyak bagi kesehatan manusia. Maka dari itu hal ini menjadi peluang besar untuk dikembangkan. Usaha agribisnis jamur tiram mempunyai potensi yang cukup besar, karena peluang usaha jamur tiram tidak tergantung pada kondisi musim, tidak membutuhkan lahan yang luas dan penempatan jamur yang dapat disusun secara bertingkat (Sucipto, 2015). Selanjutnya Hendro (2014) juga menjelaskan bahwa Budidaya jamur memanfaatkan limbah organik sehingga menjadikan lingkungan bersih dan sehat. Luas lahan sekitar $100 \mathrm{~m} 2$ dan bisa menampung \pm 7500 baglog dengan estimasi pendapatan Rp 200.000 per hari. Dari penjelasan tersebut kita dapat membayangkan bahwa besar peluang dan keuntungan yang diperoleh apabila melakukan budidaya jamur tiram ini.

Khasiat yang dapat diperoleh dari jamur tiram juga cukup banyak, asam amino yang terkandung dalam jamur tiram berjumlah 9 jenis dari 20 asam amino yang dikenal, diantaranya leusin, isoleusin, histidin, fenilalanin, lisin, methionin, triptopan, teonin, dan valin. Selanjutnya Syammahfuz (2009) menjeaskan bahwa Asam amino ini menyerupai derivat protein daging ayam. Jamur tiram putih dikenal sebagai jamur yang mudah dibudidayakan dan banyak dikembangkan pada media substrat kayu yang telah dikemas dalam kantung plastik kemudian di inkubasikan dan dipelihara di dalam rumah kubung. Karena besarnya kandungan gizi yang dimiliki oleh jamur tiram membuat masyarakat menyukainya karena disamping gampang untuk mengolahnya dan juga murah harganya dibandingkan dengan sumber protein lainnya.

Saat ini Sumatera Barat terus mengalami peningkatan produksi jamur tiram, berdasarkan data dari BPS tahun 2016 dapat dilihat dari tahun 201-2014 yaitu dari $17,52 \% \mathrm{ton} / \mathrm{m}^{2}$ menjadi 139 , $99 \mathrm{ton} / \mathrm{m}^{2}$, hal ini membuktikan bahwa banyaknya peminat jamur tiram yang didukung oleh produksi jamur tiram tersebut. Di kota Padang sendiri saat ini juga telah banyak terdapat pelaku budidaya jamur, salahsatunya daerah Tunggul Hitam tepatnya berada di Jl. Cikarau Kelurahan Dadok Tunggul Hitam Kecamatan Koto Tangah Kota Padang. Banyaknya pembudidaya jamur tiram di daerah ini sehingga menjadikan daerah ini sebagai kampung jamur. Kampung jamur ini juga telah banyak dikenal dan banyak melakukan kemitraan dengan instansi pemerintah dan juga BUMN. Dengan adanyanya kampung jamur ini sangat membantu masyarakat didalam mengoptimalkan potensi alam yang mendukung serta mampu memanfaatkan peluang dari budidaya jamur yang saat ini banyak diminati oleh masyarakat.

\section{LANDASAN TEORI}

Pemberdayaan didasarkan pada penguatkan kemampuan dan kekuatan masyarakat dalam menghadapi berbagai kondisi kehidupan yang ada, sehingga bisa bertumpu pada kemampuannya sendiri, dan tidak bergantung pada pihak yang lain (Ardiwinata \& Mulyono, 2018). Berbagai kemampuan tersebut diharapkan dapat mengembangkan partisipasi masyarakat dalam proses pembangunan di daerahnya, baik dalam mendorong perputaran potensi ekonomi maupun sosial untuk proses sosial yang ada di dalamnya. Pemberdayaan tidak hanya melibatkan sektor masyarakat dalam konteks kemanusiaan secara tunggal, tapi juga membangun sebuah karakter yang saling terlibat, termasuk diantaranya penguatan peran perempuan dalam berbagai kehidupan sosial (Karwati, Ansori \& Mulyono, 2018). Bahkan sangat dimungkinkan bilamana proses pemberdayaan melibatkan banyak sistem sosial secara terpadu, maka akan mengembangkan pula kesadaran ekologi yang ada diantara masyarakat sekitar itu sendiri (Fitriana \& Mulyono, 2019). Dengan demikian, pemberdayaan masyarakat tidak hanya berkaitan dengan bagaimana sistem pelatihan atau pendampingan semata, tapi juga 
140 Putri, Kampung Jamur Sebagai Bentuk Pemberdayaan Masyarakat Di Cikarau Kelurahan Dadok Tunggul Hitam Kecamatan Koto Tangah Kota Padang

harus mengembangkan sebuah kesadaran secara sosial dan melibatkan berbagai komponen lingkungan lainnya (Saepudin \& Mulyono, 2019). Dalam penelitian ini, dengan mengkaji pemberdayaan masyarakat melalui pengembangan kampung jamur, diharapkan dapat mengembangkan sebuah kerangka program yang lebih lengkap, terkait dengan pemberdayaan masyarakat di Cikarau, Kelurahan Dadok Tunggul Hitam, Kecamatan Koto Tengah, Kota Padang. Karena proses pembangunan kampung jamur ini melibatkan berbagai komponen sosial, organisasi kemasyarakatan juga program dalam konservasi ekologi yang berkaitan dengan budidaya jamur.

\section{HASIL DAN PEMBAHASAN}

\section{Pemberdayaan Masyarakat}

Pada dasarnya pemberdayaan (yang merupakan proses) menjadi manusia sebagai pribadi yang berdaya dengan banyaknya pilihan-pilihan yang bisa diambil tanpa ada tekanan atau paksaan. Dan makna lain berdaya itu adalah ketika tersedianya pilihan-pilihan untuk memilih atau memiliki sesuatu. Selain itu secara sederhana pemberdayaan itu adalah suatu proses memberiak daya kepada orang-orang yang tidak atau belum berdaya. Dalam hal ini masyarakat tidak hanya menjadi objek dari pemberdayaan yang diusahakan, tetapi juga sekaligus menjadi subjek dari pemberdayaan itu sendiri. M. Anwas (2013) mengatakan dengan pembangunan yang berpusat pada manusia, yaitu pada upaya peningkatan taraf hidup masyarakat dengan memfokuskan pada pemberdayaan dan pembangunan manusia itu sendiri.

Berangkat dari hal di atas masyarakat di Cikarau ini berusaha untuk membuat mereka berdaya. Berawal dari banyaknya limbahnya serbuk kayu somel di daerah tempat tinggalnya, sehingga bisa dimanfaatkan untuk dijadikan baglog sebagai langkah awal mendirikan usaha jamur tiram ini. Masyarakat mengumpulkan serbuk kayu yang sudah tidak terpakai menjadi baglog atau media penanaman jamur. Seperti yang diketahui jamur tiram ini budidayakan dengan memakai media serbuk kayu. Baglog adalah media tanam untuk meletakkan bibit jamur tiram. Karena jamur tiram merupakan jamur kayu, sehingga bahan utama dari baglog adalah serbuk gergaji. Baglog dibungkus plastik berbentuk silender, yang dimana salah satu ujungnya diberi lubang. Di lubang inilah jamur tiram akan tumbuh menyembul keluar.

Masyarakat Cikarau sebagai pembudidaya jamur tiram terdiri dari budidaya jamur tiram skala besar dan budidaya jamur tiram skala kecil. Pada budidaya jamur tiram skala besar, petani jamur biasanya membuat baglog sendiri. Namun bagi pemula, biasanya baglog dibeli dari pihak lain. Sehingga petani bisa fokus hanya menjalankan usaha budidaya saja tanpa harus membuat baglog sendiri.

Dalam pelaksanaan budidaya jamur tiram ini masyarakat saling mebelajarkan dan bekerjasama untuk mendapatkan hasil panen yang banyak. Pembudidaya di Cikarau ini juga saling membantu seperti membantu apabila salah satu pembudidaya di Cikarau ini mengalami masalah dalam budidaya jamur tiramnya. Masayakat di Cikarau ini masih menjunjung prindip bergotong royong bahkan dalam bidang bidang budidaya, walaupun usaha mereka sama namun tidak ada yang saling menjatuhkan. Sehingga desa ini menjadi Kampung Jamur karena kesepakatan mereka dalam memberdayakan masyarakatnya dan memajukan perekonomian masyarakat. 


\section{Pengolahan Jamur Menjadi Berbagai Makanan}

Jamur sebagai salah satu makanan yang disukai oleh masyarakat. Selain rasanya yang enak, murah, dan bergizi tinggi. Biasanya masyarakat mengolah jamur menjadi sayur bening, tumis dan balado. Menu olahan dari jamur ini dijakdikan lauk oleh keluarga dalam pemenuhan gizi dan penambah nafasu makan untu keluarga. Namun tanaman spora ini juga bisa diolah menjadi berbagai olahan makanan dan cemilan. Di Cikarau saat ini pemberdayaan masyarakat juga sampai pada pengolahan jamur menjadi bahan makanan kain selain sayur dan lauk sebagai teman nasi. Masyarakat pembudidaya juga mnegolah jamur menjadi cemilan seperti jamur crispi, rendang jamur, dendeng jamur dan keripik jamur.

Masyarakat sebagai pelaku budidaya dan juga sebagai pelaku pengolah makanan. Masyarakat Cikarau berusaha menambah penghasilan mereka melalui kreasi makanan dari jamur yang mereka panen. Olahan makanan berbahan dasar jamur ini juga mereka pasarkan dengan cara menjual sendiri dan memasarkannya ke berbagai cafe dan restoran di kota padang. Salah satu olahan jamur yang digemari amsayarakat adalah jamur crispi, jamur yang dibalur dengan tepung dan digoreng ini menjadi jajanan dan cemilan bagi setiap kalangan. Mulai dari anakanak, remaja, dewasa hingga orangtua menyukai jamur crispi ini. Rasa jamur yang enak dan kenyal dicampur tepung yang gurih membuat siapa saja yang memakamnnya menjadi ketagihan. Pada jamur crispi ini juga tersedia varian rasa yang semakin menambah kelezatannya. Pedagang jamur ini tak lain adalah warga cikarau yang membudidayakan jamur itu sendiri. Masyarakat mendapakan penghasilan lebih dari biasanya karena menjual olahan makanan dsri jamur diminati dan enak.

Sedangkan untuk olahan lain warga Cikarau ini menyediakannya dalam kemasan dengan berbagai ukuran. Packagingnya yang menarik membuat penikmat jamur semakin tertarik untuk membeli. Sebagian konsumen membeli olahan jamur seperti rendang jamur dan dendeng jamur karena penasaran bagaimana rasanya. Namun ketika mereka mencobanya langsung ketagihan dan membeli lagi. Hal ini dimafaatkan oleh masyarakat untuk memproduksi olahan jamur dengan kuantitas yang banyak dan kualitas yang bagus hingga terasa enak dan tidak menghilangkan kandungan gizi dari jamur itu sendiri.

\section{Mitra Sebagai Salahsatu Pendukung Pemberdayaan Masyarakat Di Kampung Jamur.}

Sebagai pelaku usaha budidaya Jamur tiram pastinya tidak berjalan sendiri. Banyak sektor yang dilibatkan dalam pelaksaan hingga pemasaran. Dari awal kegiatan budidaya pelaku usaha sudah mulai memikirkan bagaimana mendapatkan bahan dasar baglog dan bibit spora yang nanti akan tumbuh menjadi jamur tiram putih. Tak kalah penting dari itu masyarakat harus menyiapkan kumbung atau rumah jamur yang mampu menjaga sushu dan kelembaban karena akan sangat berpengaruh kepada pertumbuhan dan kualitas jamur. Kumbung biasanya berupa sebuah bangunan atau ruangan yang diisi dengan rak-rak untuk meletakkan baglog. Kumbung biasanya terbuat dari bambu atau kayu. Dinding kumbung bisa dibuat dari papan. Atapnya kamu bisa menggunakan genteng. Dianjurkan untuk tidak menggunakan atap asbes atau seng, karena akan mendatangkan panas. Sedangkan pada bagian lantainya tetap menggunakan tanah, agar air yang digunakan untuk menyiram jamur bisa meresap (liputan6.com).

Di dalam kumbung dilengkapi dengan rak berupa kisi-kisi yang dibuat bertingkat. Rak tersebut berfungsi untuk menyusun baglog. Rangka rak bisa dibuat dari bambu atau kayu. Posisi rak diletakkan berjajar dan antara rak satu dengan yang lain dipisahkan oleh lorong untuk perawatan. Ukuran kumbung yang dianjurkan sebaiknya tidak kurang dari $40 \mathrm{~cm}$. Rak bisa dibuat hanya 2 - 3 tingkat saja. Lebar rak $40 \mathrm{~cm}$ dan panjang setiap ruas rak 1 meter. Setiap 
142 Putri, Kampung Jamur Sebagai Bentuk Pemberdayaan Masyarakat Di Cikarau Kelurahan

Dadok Tunggul Hitam Kecamatan Koto Tangah Kota Padang

ruas rak sebesar ini mampu menyimpan 70 - 80 baglog. Banyaknya rak sendiri disesuaikan dengan jumlah baglog yang akan dibudidayakan.

Dari tatacara penyedian kumbung sebagai rumah jamur dapat dibayangkan peralatan apa saja yang diperlukan oleh masyarakat untuk membuatnya. Mulaidari pondasi ruangan, kayu, rak dan segala macam bahan yang digunakan untuk membangun kumbung. Hal ini membuat masyarakat harus mempersiapkan dengan matang dana awal sebagai modal untuk membuat kumbung, membuat baglog dan bibit spora. Tidak semua warga yang awalnya memiliki modal untuk budidaya ini namun memiliki keinginan yang kuta untuk ikut budidaya karena melihat kesuksesan warga lainnya.

Dalam hal ini warga bersama pemuka setempat mencarikan jalan untuk dapat membantu warga yang tidak memiliki modal awal untuk usaha budidaya jamur dengan cara mengajukan pinjaman mikro kepada pihak BUMN. Setelah berhasil mereka mengembalikan dana tersebut. Dan hal ini terus dilakukan warga dalam hal mengembangkan usahanya. Melihat kemajuan dan kondisi kampung jamur Cikarau semakin menggeliat pihak BUMN mau bekerjasama dalam hal peminjaman dana mikro dan menengah untuk membantu masyarakat atau warga yang ingin memulai atau mengembangkan saha budidaya jamurnya. Selanjutnya kempaung jamur ini bekerjasama atu bermitra dengan dinas industri Kota Padang sehingga banyak sekali dampak positif yang dapat dilihat contohnya masyarakat yang membudidayakan jamur diberikan kesempatan untuk tampil distand-stand setiap kali pameran yang dilakukan oleh Dinas Industri kot Padang. Hal ini dilakukan sebagai salahsatu media promosi pengolahan makanan berbahan dasar jamur dari kampung jamur. Selain itu para pembudidaya jamur di Cikarau juga bekerjasama dengan pihak cafe dan restoran yang ada di kota Padang dalam hal memasok hasil panen jamur tiram kepada cafe dan restoran dan tempat promosi makanan olahan jamur yang yang dibuat oleh warga.

Dari hal ini dapat dilahta bahwa pelaksanaan pemberdayaan membutuhkan beberapa elemen dan melibatkan stekholder yang dapat membantu usaha budidaya dan pengolahan jamur di Cikarau ini dapat berjalan dengan sukses. Kemitraan yang dijalan juga menentukan bagaimana proses kesuksesan dalam menjalankan usaha. Kemitraan merupakan suatu strategi bisnis yang dilakukan oleh dua pihak atau lebih dalam jangka waktu tertentu untuk meraih keuntungan bersama dengan prinsip saling membutuhkan dan saling membesarkan (Hafsah, 2000 : 43). Dengan melibatkan mitra yang dapat bekerjasama dengan baik akan mengahasilkan keuntungan dan keberlanjutan usaha yang baik pula.

\section{KESIMPULAN}

Kampung Jamur Cikarau merupakan salah satu daerah sentra pengembangan usaha jamur tiram putih. Kampung Jamur Cikarau terletak di Jalan Cikarau Kelurahan Dadok Tunggul Hitam Kecamatan Koto Tangah Kota Padang Provinsi Sumatera Barat. Kampung jamur ini merupakan salah satu bentuk pemberdayaan masyarakat yang mampu membuat masyarakat bangkit dari kekurangan ekonomi. Banyak warga Cikarau yang mengikuti kesuksesan warga yang telah sukses membudidayakan jamur tiram ini. Selain penghasil jamur tiram yang mentah Kampng Jamur ini juga menjadi sentra pengolahan jamur menjadi makanan dengan berbagai varian seperti dendeng jamu, rendang jamur, jamur crispi dan keripik jamur. Semua hasil olahan dipasarkan oleh masyarakat dengan jalan menjual sendiri dan menjualnya di cafe-cafe dan restoran di kota Padang. Sukses membudidayakan jamur tiram hingga hampir sebagian masyarakat Cikarau sebagai pembudidaya jamur membuat daerah ini diberi nama "Kampung 
Jamur". Kampung Jamur ini juga telah bermitra dan bekerjasama dengan pihak BUMN, dinas industri cafe dan restoran di kota Padang.

\section{DAFTAR PUSTAKA}

Ardiwinata \& Mulyono. 2018. Community Education in the Development of The Community. Empowerment: Jurnal Ilmiah Program Studi Pendidikan Luar Sekolah 7(1), 25-35.

Badan Pusat Statistik. 2016. Produksi Tanaman Hortikultura Provinsi Sumatera Barat Fitriana \& Mulyono. 2019. Implication of Internship III Program on Ecological Awareness of Cihampelas Village Community. Jurnal Ilmiah P2M STKIP Siliwangi 6(2), 203-208.

Hafsah, Mohammad Jafar. 2000. Kemitraan Usaha: Konsepsi dan Strategi, Jakarta: PT. Pustaka Sinar Harapan.

Hendro B. 2014. Pelatihan budidaya jamur. Universitas Gajah Mada. UGM.

Karwati, Ansori \& Mulyono. 2018. Women Empowerment to Build Entrepreneurship. Journal of Nonformal Education 4(2), 169-176.

Nasution J. 2016. Kandungan Karbohidrat dan protein jamur tiram putih (Plearotus Ostreatus) pada media tanam serbuk kayu kemiri (Aleurites Moluccana) dan serbuk kayu campuran. Jurnal Eksakta Volume 1.

Saepudin \& Mulyono. 2019. Community Education in Community Development. Empowerment: Jurnal Ilmiah Program Studi Pendidikan Luar Sekolah 8(1), 65-73.

Syammahfuz, Chazali \& Pratiwi P.S. 2009. Usaha jamur tiram skala rumah tangga. Penebar Swadaya. Bogor.

Sucipto, Edi. 2015. Analisis pengaruh kekuasaan, kemitraan dan kewirausahaan terhadap kinerja bisnis jamur tiraam putih (Pleurotus Ostreatus) di Kabupaten Jember. Thesis IPB. Bogor. 